\title{
ЛАТИНОАМЕРИКАНСЬКА ПРЕСА ПРО СИТУАЦІЮ В УКРАЇНІ У 2014-2019 рр.: МЕЖІ ДИСКУСІї
}

\author{
Юрій Мельник \\ Львівський національний університет імені Івана Франка, \\ вул. Генерала Чупринки, 49, 79044, Львів, Україна \\ e-mail: melnykiurii@gmail.com \\ https://orcid.org/0000-0002-2825-9925
}

У статті окреслено протистояння проукраїнського та проросійського трактування українського питання на матеріалі латиноамериканської преси. За приклад взято провідний мексиканський щоденник El Universal та офіційний орган Центрального комітету Комуністичної партії Куби Granma. Контраст між інтерпретаціями обох видань, явно проукраїнським та явно проросійським, відображає безкомпромісність російсько-української інформаційної війни у глобальному масштабі.

Ключові слова: латиноамериканські медіа, українське питання, війна на Донбасі, El Universal, Granma.

Постановка проблеми. До 2014 р. Україна не мала свого унікального образу у таких віддалених регіонах світу, як Латинська Америка. Як на рівні масової свідомості, так і на рівні медіа вона зливалася з Росією, у кращому разі - із доволі однорідним пострадянським простором. У 2014 р. все змінилося: отримавши свій бренд “Майдан”, а після анексії Криму та війни на Донбасі - статус жертви російської агреciï №1, Україна вийшла 3-під тіні північного сусіда, вперше зарекомендувала себе як самостійний суб'єкт, одразу вступивши із цим сусідом в інформаційну війну.

На прикладах таких регіонів, як Латинська Америка, є сенс перевірити, як доносяться до різних закутків планети голоси обох учасників цієї інформаційної війни: російський, в розпорядженні якого потужні інформаційні ресурси, та український, значно слабший, але підтримуваний США та Західною Свропою.

Екзистенційна важливість прихильного до України трактування подій не лише у Свропі і США, але й у Латинській Америці, Азії та Африці, проявляється у ключові моменти на зразок голосування за резолюцію Генеральної Асамблеї ООН про територіальну цілісність України 27 березня 2014 р. На цьому голосуванні Латинська Америка виявилася розділеною: Куба, Нікарагуа, Венесуела, Болівія проголосували проти, підтримавши у такий спосіб Росію; Колумбія, Перу, Чилі, Мексика, Панама, Домініканська республіка, Гаїті та інші країни регіону навпаки підтримали територіальну цілісність України; значна частина членів ООН із цього регіону утрималася: Бразилія, Парагвай, Уругвай, Аргентина.

(C) Мельник Ю., 2020 
Мета статті - окреслити межі латиноамериканського медійного дискурсу щодо подій в Україні у 2014-2019 рр.

Джерельна база. Реалізація мети передбачає вивчення підходів до української проблематики у двох авторитетних латиноамериканських виданнях із протилежними позиціями. Прикладом прихильного до України висвітлення подій $\epsilon$ сума аналітичних та публіцистичних текстів, опублікованих у мексиканському щоденнику El Universal. Проросійською противагою El Universal може бути Granma, газета Центрального комітету Комуністичної партії Куби.

Хронологічні рамки дослідження - період збройного протистояння в Україні (2014-2019 рр.).

Методологічна основа дослідження. Використані для дослідження журналістські тексти були знайдені на офіційних сайтах відповідних видань за ключовим словом "Україна" (ісп. "Ucrania") у рубриці “Орinión”. Матеріали із нерелевантними згадками України були відсіяні, усі інші - проаналізовані шляхом застосування індукції, порівняння, класифікаційного аналізу, контент-аналізу, аналізу лексики.

Виклад основного матеріалу дослідження. Візія мексиканського EI Universal. Розбираючи українське питання у своїх публікаціях починаючи з 2014 р., El Universal доволі однозначно характеризує ситуацію, приймаючи трактування Києва та більшості міжнародної спільноти: дестабілізація України, «інтервенція в Україну», «вторгнення в Україну», «окупація сходу України», «анексія Криму», - з боку Росії, Москви, Путіна.

Автори видання констатують «російську присутність в Україні та вторгнення у Крим» (Луіс Ернесто Дербес' $)$, звинувачують Путіна в анексії Криму та підтримці українських сепаратистів на сході України (Ектор Карденас²), засуджують Росію за вторгнення в Україну та окупацію Криму, сіяння хаосу та дезінформації через ферми ботів всередині України (Артуро Сарухан ${ }^{3}$ ), дорікають Росії Путіна за повернення до «історичних імперських претензій», продемонстрованих у Криму та в інших регіонах України (Луїс Еррера-Лассо ${ }^{4}$ ).

Щоденник наводить промову президента України Порошенка на День незалежності («Ворог не зумів поставити Україну на коліна»5); цитує нобелівську лауреатку Світлану Алексієвич, яка «не відчуває поваги до русского міра Сталіна і Путіна», зате «визнає, що “дуже” любить Україну», «була на Майдані і плакала перед фотографіями небесної сотні» .

Одне з типових висловлювань на цю тему авторства Луїса Еррери-Лассо [Luis Herrera-Lasso]: «У 2015 році Росія застосувала військову модель територіального завоювання в Україні. Всьому передували дії недержавних суб’єктів, але у випадку

\footnotetext{
$\overline{1}$ Derbez, L. E. (2017), "Trump se lanza al mundo", El Universal, 21 de mayo, disponible en: t.ly/JwMOB

2 Cárdenas, H. (2017), "Una ruptura que a nadie conviene", El Universal, 9 de abril, disponible en: t.ly/ ZkRw8

3 Sarukhán, A. (2017), “Guerra Fría 2.0”, El Universal, 5 de abril, disponible en: t.ly/BO5q2

4 Herrera-Lasso L. (2017), "Siria: sin rumbo y sin timón”, El Universal, 14 de abril, disponible en: t.ly/ $\underline{\mathrm{dbDmY}}$

5 El Universal (2016), “«Enemigo no ha podido poner de rodillas a Ucrania»: Presidente", 24 de agosto, disponible en: $\mathrm{t} . \mathrm{ly} / \mathrm{y} 01 \mathrm{x} 2$

6 El Universal (2015), "No siento respeto por el mundo de Putin: Alexiévich", 8 de octubre, disponible en: t.ly/20yrN
} 
Росії чітко йшлося про державу, яка, щоб замаскувати свою загарбницьку війну, послала солдат без розпізнавальних знаків» ${ }^{\text {. }}$

Публіцисти, які регулярно пишуть на тему України на сторінках El Universal, це Жан Меєр, Маурісіо Мешулам, Вальтер Астіе́-Бургос, Енріке Берруга Філлой та деякі інші.

Заводячи мову про Україну у своїй публіцистиці, мексиканський історик французького походження Жан Меср систематично характеризує Росію як агресора і Україну як жертву агресії: Україна розірвала свої історичні зв’язки з Росією, втекла 3-під московського впливу і наблизилась до Заходу, чим спровокувала Путіна на агресивні кроки ${ }^{8}$. Російська армія працювала проти Грузії у 2008 р., і проти України починаючи з 2013 p. ${ }^{9}$. Москва анексувала Крим та підготувала сепаратистські рухи на сході країни ${ }^{10}$. Владімір Путін «продовжує рухати свої фігурки, а останній його крок - це війна проти України, і ніхто не зможе йому відповісти» ${ }^{11}$. Він використовує обставини, серед інших - помилки українського уряду ${ }^{12}$.

У листопаді 2015 р. у статті “А Крим?” Меєр описує історію переходу з рук в руки, а також сучасні реалії окупованого Росією півострова, на якому зазнають утисків кримські татари: «Їхні релігійні школи закрили. Усі крім однієї, іноді iз застосуванням насильства». Страждають i християнські конфесії, усі крім Московського патріархату13. Кримчанин Олег Сенцов - приклад нового дисидента, який вписується як у традицію радянських політичних в'язнів, так і сучасних російських. Йому Меєр восени 2018 р. присвячує дві статті, у яких детально описує Сенцова як героя, згадує про сфабриковані звинувачення проти нього, про геройське голодування впродовж 145 днів, про світову солідарність митців та інтелектуалів, які підписали петицію за його звільнення ${ }^{14}$. Констатуючи безсилля Свропи, Меєр співчуває Україні у ii скрутному становищі: «Москва заперечує, всупереч усім фактам, своє вторгнення. [Європейський] союз нездатний на адекватне зусилля $\mathrm{i}$ Україна мусить почуватися покинутою, якщо не зрадженою» ${ }^{15}$.

Жан Меєр є автором двох статей, спровокованих наданням томосу Православній церкві України. У них - міркування про те, як політики (і Путін, і Порошенко) інструменталізують релігію ${ }^{16}$, та «використовують церкви як батальйони підкріп-

7 Herrera-Lasso L. (2017), "Las guerras del siglo XXI", El Universal, 22 de diciembre, disponible en: t.ly/x1e2Y

8 Meschoulam M. (2018), "Ucrania-Rusia y la cancelación de la cumbre Trump-Putin”, El Universal, 1 de diciembre, disponible en: t.ly/L93rA

9 Meyer J. (2017), "Operación Trump", El Universal, 6 de agosto, disponible en: t.ly/edkwN

${ }^{10}$ Meyer J. (2019), "La religión al servicio del Estado", El Universal, 20 de enero, disponible en: t.ly/ dbDm1

${ }^{11}$ Meyer J. (2018), "Previsible, imprevisible", El Universal, 30 de diciembre, disponible en: t.ly/G8VEr

${ }^{12}$ Meyer J. (2018), “iVaya, vaya, Vladimir Vladimirovich!”, El Universal, 28 de agosto, disponible en: t.ly/20yrd

${ }_{13}$ Meyer J. (2015), “¿Y Crimea?”, El Universal, 30 de noviembre, disponible en: t.ly/xle2q

${ }^{14}$ Meyer J. (2018), "Un héroe va a morir", El Universal, 9 de septiembre, disponible en: t.ly/OWErJ; Meyer J. (2018), "Los nuevos disidentes", El Universal, 4 de noviembre, disponible en: t.ly/OWErJ

${ }^{15}$ Meyer J. (2019), "Europa al pie del muro", El Universal, 19 de mayo, disponible en: t.ly/RWyJV

${ }^{16}$ Meyer J. (2019), "La religión al servicio del Estado", El Universal, 20 de enero, disponible en: t.ly/ $\underline{\mathrm{dbDm} 1}$ 
лення ${ }^{17}$. Пишучи про зустріч папи Франциска і патріарха Кирила на Кубі, Меєр пояснює вибір місця віддаленістю від Свропи, від України, яка «символізує антагонізм між обома церквами» ${ }^{18}$.

Вальтер Астіе́-Бургос у 2017-2018 pр. на сторінках El Universal кілька разів коментує ситуацію з Кримом. У всіх випадках автор розцінює Україну як жертву, яка втратила територію, а Росію - як агресора: «Згідно зі зманіпульованим Москвою плебісцитом, [Крим] відокремився від України і приєднався до Російської Федерації»19; Путін «повів наступ на Україну, країну, яка хотіла зблизитися 3 Свропейським Союзом і НАТО. У 2014 році ефективним мак'явелістським ходом приєднав Крим і Севастополь до Росії, i зупинив проєвропейські прагнення розчленованої України» ${ }^{20}$; «У 2014 проєвропейські аспірації України були зупинені референдумом, який інкорпорував Кримський півострів у Федерацію Путіна., як i через “спонтанні” сепаратистські рухи у Донецьку та Луганську»²1.

В контексті венесуельської кризи Астіе́-Бургос згадує Україну як імовірну розмінну монету у торгах Вашингтону і Москви: Путін не підтримуватиме Мадуро в обмін на зміну політики СС щодо України, Криму та санкцій ${ }^{2}$. Такою ж розмінною монетою бачиться іншому автору El Universal, Нухаду Махмуду, Сирія, де Росія нарощує присутність, аби використати її у переговорах щодо України ${ }^{23}$.

Карлос Лорет де Мола [Carlos Loret de Mola] прохолодно описує правління у Росії Путіна, «наймогутнішого чоловіка у світі» ${ }^{24}$, який «кинув виклик світу, вторгнувшись у пострадянську республіку Україну» ${ }^{25}$. Розмірковуючи над потенціалом Росії, автор констатує, що ця країна далека від можливостей СРСР, адже не володіє «надзвичайно родючими землями України» ${ }^{26}$. Де Мола також критикує Росію на фоні чемпіонату світу з футболу, зауважуючи, що їй пощастило, адже Україна, «постійне нагадування про її свавілля», не кваліфікувалася на цей чемпіонат ${ }^{27}$.

Хав’єр Техадо Донде́ [Javier Tejado Dondé] згадує Україну в контексті боротьби проти дезінформації - як країну, яка, поряд із Фінляндією, демонструє успіхи у цій боротьбі, хоча «обидві оточені росіянами та їхньою вражаючою машинерією

${ }_{17}$ Meyer J. (2018), "Guerra entre iglesias", El Universal, 11 de noviembre, disponible en: t.ly/WDLkP

${ }^{18}$ Meyer J. (2016), "Del papato", El Universal, 21 de febrero, disponible en: t.ly/YW1E5

${ }^{19}$ Astié-Burgos, W. (2017), "Ciberataques rusos contra México en 2018”, El Universal, 9 de diciembre, disponible en: t.ly/5mOrp

${ }^{20}$ Astié-Burgos, W. (2018), ¿Títere del triunfante Putin?, El Universal, 21 de julio, disponible en: t.ly/ $\underline{1 \mathrm{~L} 3 \mathrm{dR}}$

${ }_{21}$ Astié-Burgos, W. (2017), "Los turbios nexos entre Trump y Putin”, El Universal, 9 de diciembre, disponible en: t.ly/OWEBJ

${ }^{22}$ Astié-Burgos, W. (2019), “El embrollo geopolítico de Venezuela”, El Universal, 10 de mayo, disponible en: t.ly/1JGdA

${ }^{23}$ Mahmoud, N. (2017), "Señales confusas", El Universal, 9 de marzo, disponible en: t.ly/dbDvz

${ }^{24}$ Loret de Mola, C. (2018), "El hombre del que nos deberíamos ocupar más en México", El Universal, 19 de septiembre, disponible en: t.ly/pGdeO

${ }^{25}$ Loret de Mola, C. (2018), "El conejo blanco y el zorro rojo", El Universal, 19 de julio, disponible en: t.ly/1JGd7

${ }^{26}$ Loret de Mola, C. (2018), "El hombre del que nos deberíamos ocupar más en México", El Universal, 19 de septiembre, disponible en: t.ly/pGdeO

${ }^{27}$ Loret de Mola, C. (2018), “El paraguas del campeón”, El Universal, 16 de julio, disponible en: t.ly/6mpOz 
дезінформації». Автор відзначає, що «Україна щорічно тренує 15 тис. осіб, а ці, в свою чергу, готують інших людей» ${ }^{28}$. Енріке Берруга Філлой теж чітко говорить про те, що Росія захопила частини території України ${ }^{29}$ та про «присутність російських бойовиків на Сході України» ${ }^{30}$. Він вважає колосальні витрати США на озброєння марно витраченими грішми, адже вони не допомогли закінчити конфлікту у Сирії, досягнути денуклеаризації Північної Кореї чи «вигнати росіян із територій, забраних в Україні $»^{31}$.

У 2017 р., характеризуючи дії Росії, Маурісіо Мешулам пише: «Росія вирішила діяти твердо у своїх сферах впливу, рішуче вторглася в Україну, спершу захопивши та приєднавши Крим, пізніше підтримавши озброєне повстання у цій країні, яка, як здавалося Путіну, вислизала йому з рук» ${ }^{32}$. В іншій своїй статті цей автор доволі вдало визначив трагедію України: «Російська анексія Криму та російська інтервенція в Україну є для Путіна темами “внутрішньоукраїнськими”, а для Трампа - темами

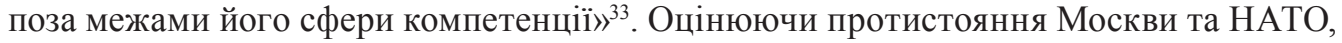
яке підійшло до рівня, небаченого з часів Холодної війни, Мешулам вчергове згадує «анексію Криму» та «підтримку сепаратистського повстання на українській території» ${ }^{34}$.

Разом 3 тим, у Маурісіо Мешулама є матеріал, у якому він описує інцидент у Азовському морі, внаслідок якого Росія захопила 24 українських моряків: «Інцидент, про який я кажу, трапився в Азовському морі, у Керченській протоці, що з'єднує морем російську територію із Кримським півостровом, територією українською. Ну, в теорії, адже після того, як Росія окупувала і анексувала Крим у 2014 році, для Москви це протока, яка об'єднує, тепер уже мостом, дві частини своєї території». Далі йде короткий опис конфлікту в обох версіях, зауваження про важливість Кримського півострова та історію його переходу із рук в руки. Очевидно, з огляду на свої уявлення про журналістські стандарти, Мешулам дає підкреслено безсторонню оцінку української проблеми, викладаючи обидві версії інциденту, як російську, так і українську: «Згідно з російською версією... За версією Києва ...». Із такою ж безсторонністю він передає обидві популярні у світових медіа інтерпретації мотивів сторін: «Відповідно до деяких текстів, Київ навмисно провокує ескалацію напруження, 3 метою реанімувати та поставити на порядок денний цю серію невирішених питань, про які багато хто, як видається, забув... Згідно з іншим тлумаченням, можливо, що саме Росія спровокувала і користається цим інцидентом... Не вперше російський президент використовує націоналістичні настрої, які у минулому видавалися напрочуд плідними для катапультування його

${ }^{28}$ Tejado Dondé, J. (2017), “Secretos del pasado sismo 19-S”, El Universal, 26 de septiembre, disponible en: t.ly/bN5Dk

${ }^{29}$ Filloy, E. B. (2016), "El preferido del zar", El Universal, 11 de agosto, disponible en: t.ly/YW1LY

${ }^{30}$ Filloy, E. B. (2018), "Un nuevo ejército", El Universal, 20 de septiembre, disponible en: t.ly/zrRwj

${ }^{31}$ Filloy, E. B. (2018), "Autoritarismo digital”, El Universal, 27 de diciembre, disponible en: t.ly/DBDry

${ }^{32}$ Meschoulam, M. (2017), "El mundo que deja Obama", El Universal, 21 de enero, disponible en: t.ly/ $\underline{\text { L3OD }}$

${ }_{33}$ Meschoulam, M. (2017), "Ecos de Helsinki: La ambigüedad en la relación Trump-Putin”, El Universal, 17 de julio, disponible en: t.ly/7qLMw

${ }^{34}$ Meschoulam, M. (2017), "EU-Rusia: las tensiones crecen a pesar de Trump", El Universal, 29 de julio, disponible en: t.ly/M6jmZ 
образу...» ${ }^{35}$. Висновок автора теж підкреслено незаангажований, безсторонній, iз акцентом на вибухонебезпечному потенціалі ситуації та потребі «зробити все необхідне для послаблення мотузки, негайної деескалації кризи» ${ }^{36}$.

Це не єдиний матеріал El Universal iз альтернативним трактуванням української проблеми. У червні 2016 р. газета взяла інтерв'ю у Рубена Руїса-Рамаса ${ }^{37}$, який, уникаючи симпатій до будь-якої зі сторін, оцінює природу конфлікту на Донбасі: «Хоча більшість повстанців - українці, народні республіки не життєздатні без підтримки Росії. Але ми повинні розрізняти підтримку Росії і підтримку окремих росіян, які там воюють і працюють там, ймовірно, за сприяння Москви, але без організаційної підтримки» ${ }^{38}$.

Візія кубинського щоденника Granma. Як і мексиканська El Universal, кубинська Granma впродовж останніх п'яти з половиною років пише про Україну у зв’язку з Майданом, Кримом та війною на Донбасі. От тільки оцінки ситуації у матеріалах Granma мають кардинально протилежний, проросійський характер.

Показовим є вже словник, яким послуговуються автори публікацій, характерна російська медійна стилістика: Київ «бомбардує східні міста на прикордонні 3 Росією» ${ }^{39}$; Росії «накидають - без жодної на те підстави - відповідальність за те, що відбувається в Україні» (в тому числі - за МН17) 40 ; Росію піддають санкціям «за її тверду позицію щодо України»; Росія «виступила за пошук мирного рішення шляхом діалогу між українською владою та непокірними жителями у кількох містах цієї нації» ${ }^{41}$

В той час як Росія, в інтерпретації газети, - борець за мир в Україні, з одного боку, та жертва несправедливих санкцій - з іншого, джерелом крові та нестабільності в Україні бачаться західні сили: «Вашингтон спорядив фашистів Майдану на площі в Україні, розв'язавши конфлікт, якому не видно кінця» ${ }^{42}$; «Нинішня військова присутність НАТО та Сполучених Штатів у цій зоні у час, коли в Україні відбувається громадянська війна $з$ іноземним втручанням, будучи замаскованою під "гарантію демократичних виборів”, є нічим іншим, як посиленням втручання Заходу та явним бажанням оточити Росію своїми ракетами» ${ }^{43}$.

Видання розлого цитує російську експертку Вероніку Крашеннікову: «...Неконституційний державний переворот та незаконне відсторонення президента

\footnotetext{
35 У сенсі: «підвищення рейтингу».

${ }^{36}$ Meschoulam, M. (2018), "Ucrania-Rusia y la cancelación de la cumbre Trump-Putin”, El Universal, 1 de diciembre, disponible en: t.ly/L93rA

${ }^{37}$ Іспанський дослідник пострадянської дійсності, зокрема українського питання, автор книги “Україна: від революції на Майдані до війни на Донбасі' (2016) та інших текстів на цю тему. Ruiz-Ramas, R. (2016). Ucrania. De la Revolución del Maidán a la Guerra del Donbass, Comunicación Social, Salamanca, $401 \mathrm{p}$.

${ }^{38}$ El Universal (2016). "La escalada militar en el Este de Europa no ha terminado", 21 de junio, disponible en: t.ly/302wW

${ }^{39}$ Pérez, E. C. (2014), “Otra apuesta por la guerra”, Granma, 5 de septiembre, disponible en: t.ly/jOM2P

${ }^{40}$ Pérez, E. C. (2014), "Enfermiza geopolítica”, Granma, 20 de julio, disponible en: t.ly/EekDJ

${ }^{41}$ Pérez, E. C. (2014), “¿Quién aísla a quién?”, Granma, 9 de junio, disponible en: t.ly/vLp77

${ }^{42}$ Gómez S. A. (2016), "Lo que nos deja el 11 de septiembre", Granma, 9 de septiembre, disponible en: t.ly/P6dGM

${ }^{43}$ Pérez, E. C. (2014), “"Democracia» a bordo de un crucero”, Granma, 20 de mayo, disponible en: t.ly/0ldw3
} 
Віктора Януковича з підморгуючою співучастю Заходу... До влади прийшов самопроголошений уряд, сформований з одного боку агентами Заходу, а з іншого - ультранаціоналістами та фашистами... Деякі регіони сходу та півдня України не визнають уряд, установлений в Києві, і заявляють про своє бажання об'єднатися з Росією» ${ }^{44}$.

Серед публікацій Granma найбільш детально українську проблему висвітлено у статті під назвою “Україна, історія без розповіді” (22 травня 2014 р.), авторка якої, Лінет Перера Негрін [Linet Perera Negrin], інтерпретує ситуацію в Україні у перші місяці після перемоги Майдану як «численні народні протести та рішення багатьох міст східної України федералізувати цю територію». Різкого осуду з боку авторки зазнає нова українська влада, яку вона звинувачує у порушеннях прав людини у південно-східній Україні. Негрін вбачає мету операції Національної гвардії (у складі якої - «фашисти групи “Правий сектор"») «у поверненні міст, які є епіцентром руху за федералізацію і де контроль утримує ополчення самооборони, внаслідок чого виникають жорстокі зіткнення з важкою артилерією». У цьому контексті авторка називає події в Одесі «найтрагічнішим підсумком того, що багато хто називає «каральною операцією”». Проурядові формування, вважає Негрін, «мали на меті ліквідувати ті громадські сили, які були готові чинити фронтальний опір режиму, як це відбувається в Донецьку, Луганську та Слов'янську». Показово, що про Росію як фактор у цих процесах не сказано нічого ${ }^{45}$. Не згадує Негрін про російський чинник і у іншій своїй статті про Україну, датованій 2015 р., присвяченій невиконанню обіцянок Майдану та “неофашистським батальйонам” (лише на початку статті йдеться про проросійські симпатії третини українців у 2013 р. $)^{46}$.

Розглядаючи ситуацію у глобальній перспективі, Ельсон Консепсьйон Перес [Elson Concepción Pérez] згадує український Майдан поряд із буремними зрушеннями у Лівії, Сирії, “оксамитовою революцією” в колишній Чехословаччині, «так званою “помаранчевою революцією”, також в Україні». Усі ці події, на думку автора статті, об’єднує те, що вони «ніколи не були і не є революціями», а медійними абераціями, якими маніпулюють західні центри влади ${ }^{47}$. В іншому своєму тексті Перес проектує долю Лівії, Іраку та Афганістану на Сирію та Україну, які є «фокусом поточних конфліктів». Джерелом бід у названих країнах автор вважає Сполучені штати, Європу, НАТО. «Лівія - це не “закрита справа", як і Дамаск та Київ - “відкриті справи” для теперішніх та майбутніх імперських авантюр», - підсумовує Перес ${ }^{48}$.

\section{Висновки}

Впродовж 2014-2019 рр. українська проблематика є доволі популярною темою для латиноамериканської преси. Медіа регіону, які осмислюють українське питання, доволі чітко поляризовані, майже не займаючи проміжних позицій щодо українсько-російських відносин. Взяті до уваги у статті газети репрезентують цю поляризацію, займаючи виразну проукраїнську (мексиканська El Universal) та виразну проросійську (кубинська Granma) позиції у висвітленні української проблеми. На cайті El Universal всього близько п'ятдесяти матеріалів, у яких порушено українське

\footnotetext{
${ }^{44}$ Ochoa, O. B. (2014), "Ucrania en la mira geopolítica de Occidente”, Granma, 14 de marzo, disponible en: $\underline{t . l y / A x Y q X}$

${ }^{45}$ Negrin, L. P. (2014) "Ucrania, una historia sin contar", Granma, 22 de mayo, disponible en: t.ly/n18Lr

${ }^{46}$ Negrin, L. P. (2015), “A un año del Maidán”, Granma, 24 de febrero, disponible en: t.ly/JwMKm

${ }^{47}$ Pérez, E. C. (2014), “'Revolución en Siria?”, Granma, 8 de mayo, disponible en: t.ly/ZkR6N

${ }^{48}$ Pérez, E. C. (2014), “Libia: ¿un caso cerrado?”, Granma, 16 de abril, disponible en: t.ly/Xje19
} 
питання ${ }^{49}$, із яких лише кілька не витримані у явно проукраїнському (антиросійському) ключі. Присвячена тій же тематиці аналітика та публіцистика у головній кубинській газеті Granma - всього близько десятка матеріалів, кожен із яких відтворює російське бачення ситуації.

Згадування України в обох виданнях майже виключно стосуються Майдану, подальших подій у Криму і на Донбасі. $\mathcal{C}$ поодинокі винятки, наприклад, Карлос Лорет де Мола описує феномен Зеленського, який скористався «незадоволенням українців своїми елітами» ${ }^{50}$. Загалом, не буде перебільшенням сказати, що Україна існує у пресі Латинської Америки як країна, яка стала жертвою російської агресії (в інтерпретації одних), або ж як країна, яка влаштувала фашистський переворот і придушує своїх незгодних громадян (в інтерпретації інших). Окреслене протистояння наративів унаочнює безкомпромісність інформаційної війни навколо України, яка на матеріалі латиноамериканської преси виявляє себе у глобальному вимірі.

Перспективи подальших досліджень пов'язуємо із необхідністю подальшого вивчення образу України у світових медіа (зокрема латиноамериканських) та чинників, які його формують.

\section{REFERENCES}

1. Astié-Burgos, W. (2017), "Los turbios nexos entre Trump y Putin”, El Universal, 9 de diciembre, disponible en: t.ly/OWEBJ

2. Astié-Burgos, W. (2018), ¿Títere del triunfante Putin?, El Universal, 21 de julio, disponible en: t.ly/lL3dR

3. Astié-Burgos, W. (2019), "El embrollo geopolítico de Venezuela", El Universal, 10 de mayo, disponible en: t.ly/1JGdA

4. Cárdenas, H. (2017), "Una ruptura que a nadie conviene", El Universal, 9 de abril, disponible en: $\underline{t . l y / Z k R w 8}$

5. Derbez, L. E. (2017), "Trump se lanza al mundo", El Universal, 21 de mayo, disponible en: t.ly/JwMOB

6. El Universal (2015). "No siento respeto por el mundo de Putin: Alexiévich", 8 de octubre, disponible en: t.ly/20yrN

7. El Universal (2016). "«Enemigo no ha podido poner de rodillas a Ucrania»: Presidente", 24 de agosto, disponible en: t.ly/y01x2

8. El Universal (2016). "La escalada militar en el Este de Europa no ha terminado", 21 de junio, disponible en: t.ly/302wW

9. El Universal (2019). “QQuién es Vladímir Zelenski, el comediante que se convirtió en presidente de Ucrania?", 22 de abril, t.ly/gyVdv

10. Filloy, E. B. (2016), “El preferido del zar", El Universal, 11 de agosto, disponible en: t.ly/YW1LY

11. Filloy, E. B. (2018), "Autoritarismo digital”, El Universal, 27 de diciembre, disponible en: t.ly/DBDry

${ }^{49}$ Сюди зараховуємо і повністю присвячені Україні статті аналітичного чи публіцистичного характеру, і тексти на інші теми, у яких Україну згадано мимохідь, але разом з тим викладена та чи інша оцінка ситуації.

${ }^{50}$ El Universal (2019). "¿Quién es Vladímir Zelenski, el comediante que se convirtió en presidente de Ucrania?", 22 de abril, t.ly/gyVdv 
12. Filloy, E. B. (2018), “Un nuevo ejército”, El Universal, 20 de septiembre, disponible en: t.ly/zrRwj

13. Gómez S. A. (2016), "Lo que nos deja el 11 de septiembre", Granma, 9 de septiembre, disponible en: t.ly/P6dGM

14. Herrera-Lasso L. (2017), "Las guerras del siglo XXI", El Universal, 22 de diciembre, disponible en: $\underline{\text { t.ly } / \mathrm{x} 1 \mathrm{e} 2 \mathrm{Y}}$

15. Herrera-Lasso L. (2017), "Siria: sin rumbo y sin timón", El Universal, 14 de abril, disponible en: t.ly/dbDmY

16. Loret de Mola, C. (2018), "El conejo blanco y el zorro rojo", El Universal, 19 de julio, disponible en: t.ly/1JGd7

17. Loret de Mola, C. (2018), "El hombre del que nos deberíamos ocupar más en México", El Universal, 19 de septiembre, disponible en: t.ly/pGdeO

18. Loret de Mola, C. (2018), "El paraguas del campeón”, El Universal, 16 de julio, disponible en: t.ly $/ 6 \mathrm{mpOz}$

19. Mahmoud, N. (2017), "Señales confusas", El Universal, 9 de marzo, disponible en: t.ly/ $\underline{\mathrm{dbDvz}}$

20. Meschoulam M. (2018), “Ucrania-Rusia y la cancelación de la cumbre Trump-Putin”, El Universal, 1 de diciembre, disponible en: t.ly/L93rA

21. Meschoulam, M. (2017), "Ecos de Helsinki: La ambigüedad en la relación Trump Putin", El Universal, 17 de julio, disponible en: t.ly/7qLMw

22. Meschoulam, M. (2017), "El mundo que deja Obama", El Universal, 21 de enero, disponible en: $\underline{\text { t.ly/lL3OD }}$

23. Meschoulam, M. (2017), "EU-Rusia: las tensiones crecen a pesar de Trump", El Universal, 29 de julio, disponible en: t.ly/M6jmZ

24. Meschoulam, M. (2018), "Ucrania-Rusia y la cancelación de la cumbre Trump-Putin", El Universal, 1 de diciembre, disponible en: t.ly/L93rA

25. Meyer J. (2015), “¿Y Crimea?”, El Universal, 30 de noviembre, disponible en: t.ly/x1e2q

26. Meyer J. (2016), "Del papato", El Universal, 21 de febrero, disponible en: t.ly/YW1E5 Astié-Burgos, W. (2017), "Ciberataques rusos contra México en 2018”, El Universal, 9 de diciembre, disponible en: t.ly/5mOrp

27. Meyer J. (2017), “Operación Trump”, El Universal, 6 de agosto, disponible en: t.ly/ edkwN

28. Meyer J. (2018), “¡Vaya, vaya, Vladimir Vladimirovich!”, El Universal, 28 de agosto, disponible en: t.ly/20yrd

29. Meyer J. (2018), "Guerra entre iglesias", El Universal, 11 de noviembre, disponible en: t.ly/WDLkP

30. Meyer J. (2018), "Los nuevos disidentes", El Universal, 4 de noviembre, disponible en: t.ly/OWErJ

31. Meyer J. (2018), "Previsible, imprevisible", El Universal, 30 de diciembre, disponible en: t.ly/G8VEr

32. Meyer J. (2018), "Un héroe va a morir", El Universal, 9 de septiembre, disponible en: t.ly/OWErJ

33. Meyer J. (2019), "Europa al pie del muro", El Universal, 19 de mayo, disponible en: t.ly/ RWyJV

34. Meyer J. (2019), "La religión al servicio del Estado", El Universal, 20 de enero, disponible en: t.ly/dbDm1 
35. Negrin, L. P. (2014), “Ucrania, una historia sin contar”, Granma, 22 de mayo, disponible en: $\underline{t .1 y / n 18 \mathrm{Lr}}$

36. Negrin, L. P. (2015), “A un año del Maidán”, Granma, 24 de febrero, disponible en: t.ly/ JwMKm

37. Ochoa, O. B. (2014), "Ucrania en la mira geopolítica de Occidente", Granma, 14 de marzo, disponible en: t.ly/AxYqX

38. Pérez, E. C. (2014), “Quién aísla a quién?”, Granma, 9 de junio, disponible en: t.ly/ vLp77

39. Pérez, E. C. (2014), “Revolución en Siria?”, Granma, 8 de mayo, disponible en: t.ly/ ZkR6N

40. Pérez, E. C. (2014), “«Democracia» a bordo de un crucero”, Granma, 20 de mayo, disponible en: t.ly/01dw3

41. Pérez, E. C. (2014), "Enfermiza geopolítica", Granma, 20 de julio, disponible en: t.ly/ EekDJ

42. Pérez, E. C. (2014), “Libia: ¿un caso cerrado?”, Granma, 16 de abril, disponible en: t.ly/ $\underline{\mathrm{Xje} 19}$

43. Pérez, E. C. (2014), “Otra apuesta por la guerra”, Granma, 5 de septiembre, disponible en: t.ly/jOM2P

44. Ruiz-Ramas, R. (2016). Ucrania. De la Revolución del Maidán a la Guerra del Donbass, Comunicación Social, Salamanca, $401 \mathrm{p}$

45. Sarukhán, A. (2017), "Guerra Fría 2.0”, El Universal, 5 de abril, disponible en: t.ly/ BO5q2

46. Tejado Dondé, J. (2017), "Secretos del pasado sismo 19-S”, El Universal, 26 de septiembre, disponible en: t.ly/bN5Dk 


\title{
LATIN AMERICAN PRESS ON THE SITUATION IN UKRAINE IN 2014-2019: THE LIMITS OF DISCUSSION
}

\author{
Iurii Melnyk \\ Ivan Franko National University of Lviv, \\ Generala Chuprynky Str. 49, 79044, Lviv, Ukraine \\ e-mail:melnykiurii@gmail.com \\ https://orcid.org/0000-0002-2825-9925
}

The article outlines the confrontation between the pro-Ukrainian and pro-Russian interpretation of the Ukrainian question on the material of the Latin American press. El Universal, the leading Mexican diary, and Granma, the official newspaper of the Central Committee of the Cuban Communist Party, are taken as examples. The polarization between the interpretations of both newspapers, clearly pro-Ukrainian and obviously pro-Russian ones, reflects the uncompromising nature of the Russian-Ukrainian information war on the global scale.

On the pages of El Universal there are nearly fifty articles that raise the Ukrainian question. Of these, only a few were not sustained in the clearly pro-Ukrainian (anti-Russian) manner. The devoted to the same topic opinion articles in the main Cuban newspaper Granma are only about a dozen in number, each of which reproduces clearly pro-Russian vision of the situation.

The mention of Ukraine in both newspapers almost exclusively concerns the Maidan and the further events in Crimea and in Donbass. There exceptions are rare, for example, Carlos Loret de Mola describes the Zelensky phenomenon, which took advantage of the "discontent of Ukrainians with their elites". In general, it would not be an exaggeration to say that Ukraine exists in the Latin American press as a country that has become a victim of Russian aggression (in the interpretation of some), or as a country that staged the fascist coup and suppresses its dissenting citizens (in the interpretation of others). The outlined confrontation between narratives clearly shows the uncompromising nature of the information war around Ukraine, which, on the material of the Latin American press, is manifested in the global dimension.

Key words: Latin American media, Ukrainian issue, Donbass war, El Universal, Granma. 